\title{
POWER LOSSES MINIMIZATION AND ENERGY ACCOUNTS IN INDUCTION MOTORS WITH NONSTATIONARY LOAD
}

\section{G. Diachenko, O. Aziukovskyi}

Dnipro University of Technology

prosp. Dmytra Yavornytskoho, 19, Dnipro, 49005, Ukraine. E-mail: diachenko.g@nmu.one

S. Yakimets

Kremenchuk Mykhailo Ostrohradskyi National University

vul. Pershotravneva, 20, Kremenchuk, 39600,Ukraine. E-mail: ysm_seem@meta.ua

Purpose. The main objective of this paper is to analyze domestic and foreign experience regarding the simultaneous electromagnetic and electromechanical transients in an electromechanical system with an electric motor based on an asynchronous machine as well as to investigate their influence in the problems of the power loss minimization when applying different control strategies to reduce the total electricity consumed from the grid. Methodology. A generalized block diagram was formed to reflect the process of converting the consumed energy from the grid into mechanical power according to the conservation law for an electromechanical converter operating in the motor mode. Mathematical modeling of an asynchronous machine was performed in the framework of indirect field-oriented control system considering the stepped trajectory of load torque, which is possible as a result of mechanical perturbation or when the motor performs complex speed profiles or counteracts shock loads. Results. A mathematical model of the investigated system addressing the magnetic flux linkage dynamics equation and mechanical torque equation obtained directly from the equivalent circuit was developed. The reference value of the field-generating current is an additional degree of freedom in the system. Hence, in order to ensure minimum energy consumption with an adequate intensity of transients in the control object, the implemented model allows for comparative analysis of different approaches to solving this problem. Originality. For the first time, a comprehensive transient analysis was performed when an asynchronous machine was operating in a non-stationary load mode and the economic effect of implementing an energy-efficient control law during the transient process was discussed. Practical value. The approach to minimizing the power loss in the dynamic mode of operation, which has the same formulation for the optimization problem in static mode and reduces peaks instantaneous power loss in dynamics. The proposed iterative approach to the energy loss account and the comparative analysis of the effect of the implementation of different optimization methods gives good results even with a simple mathematical model of the motor.

Key words: power loss minimization, dynamic mode, induction motor, nonstationary load.

\section{МІНІМІЗАЦІЯ ПОТУЖНОСТІ ВТРАТ ТА СПОЖИВАНОЇ ЕНЕРГІЇ АСИНХРОННИМИ ДВИГУНАМИ 3 НЕСТАЦІОНАРНИМ НАВАНТАЖЕННЯМ}

\section{Г. Г. Дяченко, О. О. Азюковський}

Національний технічний університет «Дніпровська політехніка»

просп. Дмитра Яворницького, 19, м. Дніпро, 49005, Україна. E-mail: diachenko.g@ @mu.one

\section{С. М. Якимець}

Кременчуцький національний університет імені Михайла Остроградського

вул. Першотравнева, 20, м. Кременчук, 39600, Україна. E-mail: ysm_seem@meta.ua

Стаття спрямована на аналіз вітчизняного та закордонного досвіду стосовно одночасного протікання електромагнітних та електромеханічних перехідних процесів в електромеханічній системі із електричним двигуном на базі асинхронної машини та дослідження їх впливу в задачах мінімізації потужності втрат в обмотках при застосуванні різних законів керування, що в свою чергу веде до зниження сумарної споживаної електроенергії $з$ мережі. У процесі дослідження була сформована узагальнена структурна схема, яка відображає процес перетворення споживаної енергії з мережі в механічну потужність як результат взаємодії обертового електромагнітного поля з активною складовою струму ротора згідно закону збереження для електромеханічного перетворювача, працюючого в режимі двигуна. Ми провели математичне моделювання асинхронної машини у складі системи векторного керування з орієнтацією по полю ротора з урахуванням ступінчатої форми зміни траєкторії моменту навантаження, яка можлива в результаті механічного збурення, а також відпрацюванні профілю швидкості з постійним прискоренням або гальмуванням. Ми розробили математичну модель електромеханічної системи керування електродвигуном в рамках системи векторного керування з урахуванням рівняння динаміки потокозчеплення та рівняння крутного моменту двигуна отримані безпосередньо зі схеми заміщення. Уставка струму намагнічування $є$ додатковим ступенем свободи в даній системі. Тобто для забезпечення мінімальних витрат енергетичних ресурсів при достатній інтенсивності протікання перехідних процесів в об'єкті керування реалізована модель дозволяє проводити порівняльний аналіз різних підходів до вирішення цієї задачі. Вперше було проведено комплексний аналіз перехідних процесів коли асинхронна машина працює в режимі з нестаціонарним навантаженням та економічного ефекту від впровадження енергоефективного закону керування під час перехідного процесу. Розглянутий підхід до мінімізації потужності втрат у динамічному режимі роботи електромеханічної системи із електричним двигуном на базі асинхронної машини з короткозамкненим ротором який має однакове формулювання як для оптимізаційної задачі у статичному режимі роботи, так і в динамічному зменшує пікові значення миттєвої потужності втрат при ступінчатій зміні навантаження на валу електродвигу- 
на. Запропонований ітеративний підхід до врахування енергії втрат та порівняльного аналізу ефекту від впровадження різних методів оптимізації дає хороші результати навіть $з$ простою математичною моделлю двигуна.

Ключові слова: мінімізація потужності втрат, динамічний режим, асинхронний двигун, нестаціонарне навантаження.

PROBLEM STATEMENT. A great part of electricity both in industrial facilities and buildings is consumed by motors, mainly by induction motors due to their high performance, high reliability, robustness, and low cost in a variety of applications from a few watts for small servomotors up to several hundreds of kilowatts.

Solutions to the problem of efficiency increase in the electromechanical system of an induction motor drive using different methods have been reported previously by many authors [1-5]. The proposed methods mainly use approaches of cascaded control and the synthesis of regulators based on classical optimization strategies. However, given the wide range of applications and heavy use, the operation in the part-loaded mode and solutions to its drawbacks were not completely analyzed. Consequently, the question of power loss minimization in dynamics has gained importance in cases when a motor drive is operated with nonstationary load.

Thus, the research towards minimization of the electric power consumption is always relevant, and the introduction of minor improvements brings tangible global economic effect.

EXPERIMENTAL PART AND RESULTS OBTAINED. Induction motor is the most common type of electric machine in the industry. They are renowned for their reliability, relatively simple design, as well as low cost.

One can be represented as an electromechanical energy converter with a complex system of a magnetically coupled stator and rotor windings. Their mutual position changes continuously when the rotor rotates. When connected to the AC network during the operation of such a complex circuit, transients constantly occur in its circuits.

A transient (or dynamic) process in induction motors is a process that occurs during the transition from one steady-state mode of operation of the motor to another, such as starting, reverse, braking, load torque step up or step down. Transient processes in the motor are described by a system of differential equations [6], which are nonlinear in nature. These equations are obtained directly from the mathematical representation of the control object, and their solution for finding the dependencies is usually made using specialized software applications. The parameters of this model are the active and inductive resistance of the equivalent circuit, which may also vary during transients.

In this regard, electromagnetic and mechanical transient processes can be distinguished. Electromagnetic processes are caused by the electromagnetic inertia of the windings, which manifests itself when currents or voltages change in the electrical circuits of the motor. The mechanical processes appear due to the presence of the moment of inertia of the rotor and the reduced moment of inertia of the end effector. The simultaneous occurrence of electromagnetic and mechanical transient processes is called electromechanical transient process. The conditions of the occurrence of electromechanical transients in an induction motor, and above all its changing magnetic field, have a significant impact on the duration of these processes. Consequently, the accuracy of working out reference signals to a large extent depends on transients. Therefore, an investigation of the transients of an induction motor is of great practical importance. The results of the analysis provide opportunities to develop control systems more rationally in order to ensure the required technological process, as well as evaluate the productivity and quality of operation of production mechanisms. The investigation of these processes with varying voltage and frequency of the network is important in the study of electromechanical systems when it is necessary to obtain the optimal nature of the transient process.

The thermal state of the motor changes simultaneously with transients. With rapid processes, a change in thermal state in most cases does not affect other processes significantly. Therefore, the temperature change in the study of transient processes in the vast majority of cases can be disregarded. However, if it is essential to take into account the influence of thermal processes, then the values of the active resistance of the windings can be changed in accordance with the temperature variation.

Transient currents in the stator and rotor windings vary in complex time dependences. In this regard, the electromagnetic torque is determined by these dependencies as a complex function of time, which strongly depends on the type of transient process and on the initial level of the magnetic field of the motor. The motor torque in the transient mode can be several times higher than the torque in the static mode due to the fact that the transient currents of the stator and rotor can significantly exceed the values for the steady-state mode of operation. The magnetic fields generated by the transient components of the currents can either strengthen or weaken the main field, causing a corresponding amplification or weakening of the transient electromagnetic torque.

Changes in currents can also be caused by changes in the rotor speed. In this case, if the increase in speed is large, then due to the influence of the inductances of the windings of the machine, the rate of change in currents drops behind the rate of change in speed. Moreover, the greater the time constants of the windings and the less the moment of inertia of the rotating masses, the more this fact is noticed. In addition, when the synchronous speed is reached, the currents in the rotor winding will not yet be equal to zero. Consequently, the electromagnetic torque is not equal to zero, which means that the motor accelerates to a speed exceeding the synchronous one. With the speed increase above the level corresponding to the synchronous one, the currents in the rotor winding are reduced. The torque developed by the motor also decreases, and then becomes negative, resulting in the rotation speed decrease. Thus, at the end 
of the transient process, the speed and torque of the motor perform damping oscillations.

The damping rate of electromagnetic transients depends on the parameters of the windings, whereas the mechanical transients depend on the moment of inertia of the rotating masses and the magnitude of the load torque. Meanwhile, two typical situations are considered. In the first case, electromagnetic transients damp much faster compared to the rate of change in the rotor speed. Therefore, the influence of electromagnetic transients can be neglected, and mechanical transients can be considered based on the equation of motion of the rotor. In the second case, the damping time constants of electromagnetic and mechanical transients are comparable. In this situation, it is highly recommended to consider both electromagnetic and mechanical transients, since omitting of electromagnetic transients often leads to an incorrect assessment of the torques acting in the electric drive system, and, consequently, to significant errors, in particular, in energy-efficient control problems.

To analyze the transients in an induction motor in a more deep and accurate manner, it is necessary to take into consideration not only the change in the energy of magnetic fields but also the change in the kinetic energy of the flywheel masses of the drive, i.e. it is recommended to analyze electromechanical transients instead.

Optimization of energy consumption of electric drive systems is a perspective area of research in the field of electrical engineering as part of a common approach to energy saving and efficient use of resources.

The rules of electromechanics formulated in the work of professor I. P. Kopylov as the three laws of electromechanics provide a summary of the physical principles that underlie the methods of designing and studying energy converters from the viewpoint of performing useful work in the process of electromechanical energy conversion. From the first rule, it follows that electromechanical energy conversion is always carried out with losses (efficiency is always less than 100\%).
Here the losses are explained due to the presence of active resistance in the windings. The second rule states that all electrical machines are reversible. It also follows from here that the inductance of the machine must be taken into consideration. These two rules are necessary but not sufficient conditions for electromechanical energy conversion. Finally, the third law of electromechanics states that transformation is carried out by fields that are motionless relative to each other. The electrodynamic processes of an electromechanical converter are determined by vector interactions of mutually moving vectors of flux linkages and currents with modules and phases varying as a function of time.

Except for losses in the stator windings and steel, the power taken by the motor is converted into the power of a rotating magnetic field (into electromagnetic power). Since an induction motor operates both as a motor and as a transformer, the electromagnetic power is divided two channels. One part of the electromagnetic power is converted into mechanical power generated on the shaft of an induction motor. This power arises as a result of the interaction of a rotating electromagnetic field with the active component of the rotor current. The remaining part of the electromagnetic power is transformed in the form of electric power into the rotor winding (as into the secondary winding of the transformer).

From the conservation law for an electromechanical energy converter operating in a motor mode, the next expression could be written down

$$
W_{G}=W_{O}+W_{F}+W_{M H}+W_{C}
$$

where $W_{G}$ - energy supplied by mains; $W_{F}$ - magnetic energy stored in a magnetic field; $W_{M H}$ - mechanical energy on the motor shaft; $W_{O}$ - the energy of other losses; $W_{C}$ - energy to compensate for electrical losses.

Summarizing the information on energy conversion, a structural diagram in Figure 1 can be given.

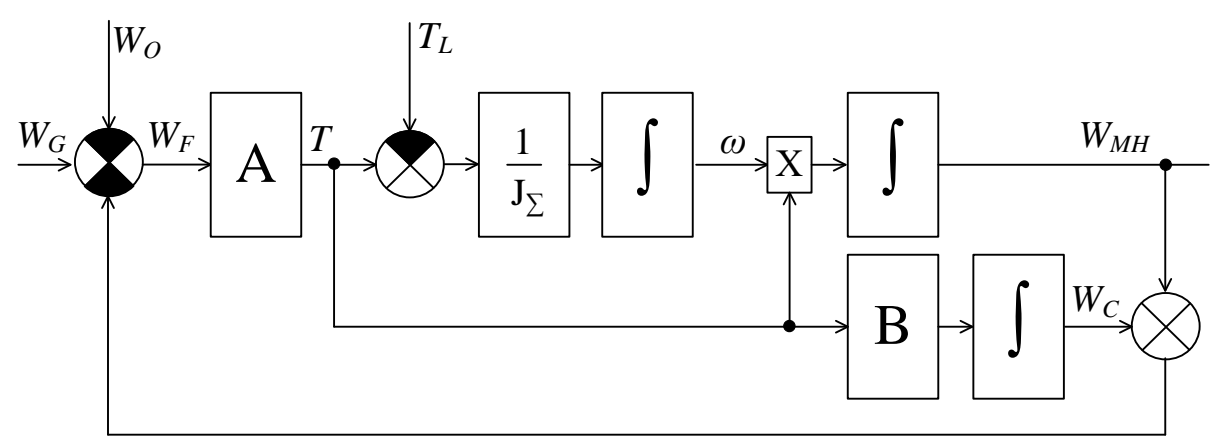

Figure 1 - Generalized structure sheme of energy flow in induction motors

The given scheme shows the stages of energy from network $W_{G}$ to a mechanical $W_{M H}$. Two operators are introduced into the scheme:

$A$ - reflects the conversion of magnetic field energy into electromagnetic torque;

$B$ - takes into account the connection of the electromagnetic torque with active losses.
In addition, the scheme involves the reduced moment of inertia $J_{\Sigma}$ and the rotational speed of the motor shaft $\omega$.

Analysis and minimization of energy losses in different operation modes of an electric drive are important both from the point of view of the economic indicators of the control system and assessment of the thermal state of the engine when selecting or checking one according to the heating conditions [7]. The following 
types of losses are determinant for an induction motor [8-9]:

- losses in copper of the stator winding and rotor winding due to the first harmonics of the winding currents;

- losses in stator steel due to hysteresis and eddy currents;

- mechanical losses;

- additional losses proportional to the square of the fundamental harmonic of the stator current.

One of the most common criteria for optimizing the steady-state operation of an induction motor fed by frequency converter is the criterion for the minimum stator current, which corresponds to the lowest power loss at the active resistances of the stator windings and semiconductor converter.

The basic principle of vector control is separate independent regulation of the field-generating current of the motor and torque-generating current, which is proportional to the mechanical torque on the shaft. Thus, the torque-generating current is always set at a minimum level as much as required to ensure sufficient mechanical torque to maintain a given rotation speed of the motor shaft as well as system dynamics. As a result, vector control has high energy efficiency.

The reference value of the field-generating current is an additional degree of freedom in the control system. It is known that the power losses of the motor in the steady-state mode of operation are a concave function of the field-generating current [9].

A large number of different power loss models and strategies for the optimal choice of the field-generating current and rotor flux linkage settings are proposed [10], [11], [12]. However, when induction motor is operated in part-loaded mode or used in a servo drive applications, in addition to steady-state modes, transient processes should also be considered when the motor performs complex speed profiles [13] or counteracts shock loads [13-14]. In such cases, methods for minimization of energy consumption in the steady-state provide optimal conditions neither in the dynamic characteristics of the drive nor in energy costs.

The optimization and search approach for optimal control provides a preliminary assessment of the dynamics of the control object. Yet, it is generally worthwhile to assemble a criterion arising from the mathematical description of the system dynamics and the initial conditions as follows

$$
J=V(x(T))+\int_{0}^{T} L(x(t), u(t)) d t \rightarrow \min ,
$$

where $0, T$ - initial and final time points of the transient process; $L$ - functional containing minimization criterion, the integral cost; $V$ - final cost; $t$ - a point of time.

In classical science, this type of criterion description uses Hamiltonian. One represents the total energy of the system and completely describes its dynamics. The Hamiltonian approach is most clearly expressed in the Pontryagin's maximum principle formulated by the Russian mathematician Lev Pontryagin. This criterion reflects the minimum energy requirements for the quality of control processes providing the demanded curves of transients. The maximum principle is used in optimal control problems to find the best possible control for taking a dynamical system from one state to another, taking into account the constraints for the state or input controls. The basic idea is that for any optimal control it is necessary to solve the so-called Hamiltonian system, which is a two-point boundary value problem, plus a maximum/minimum condition of the Hamiltonian. These conditions become sufficient under certain convexity conditions on the objective and constraint functions.

The construction of the Hamiltonian $H$ is defined for all $t \in[0, T]$ by

$$
H(x(t), u(t), \lambda(t), t)=\lambda^{T}(t) f(x(t), u(t)+L(x(t), u(t))),
$$

where $\lambda^{T}$ is the transpose of time-varying Lagrange multiplier vector $\lambda$.

The optimal state trajectory $x^{*}$, optimal control $u^{*}$, and corresponding vector of costates of the system $\lambda *$ must minimize the $H$ so that

$$
H(x *(t), u *(t), \lambda *(t), t) \leq H(x *(t), u(t), \lambda *(t), t) .
$$

Whether the extremum value is a maximum or minimum depends on the problem as well as the sign convention used for Hamiltonian calculation. The standard case leads to a maximum. Thus, it is called the maximum principle.

Therefore, the purpose of this approach is to ensure technological processes with minimum consumption of energy and material resources meanwhile providing sufficient intensity of the processes in the control object. Accordingly, the general functional $J$ can be specified for the following particular quality criteria:

- minimization of energy consumption;

- minimization of energy consumption with high control accuracy;

- minimization of transient process time.

In addition to the cases listed above, it is possible to compose various other criteria of a combined type, which will be further used when considering specific problems of the synthesis of energy-saving control laws.

One of the vital questions of the problem is the implementation of energy-efficient modes in automatic control systems of electric drives. Nowadays, due to the simplicity of the unified synthesis procedure and the methodology for setting up regulators, automatic control systems for electric drives with a cascaded control structure are widely used. There is the possibility of the most complete implementation of energy-efficient control modes within systems of this type while maintaining the quality of the static and dynamic characteristics of electric drives. Hence up to this point, the control laws had to be analyzed taking into consideration the perspective of the possibility of their further integration in automatic control systems of electric drives with a cascaded control structure.

Due to the longer prediction horizon, the strategy based on Hamiltonian approach is relatively complex in understanding and calculations compared to classical controllers. The prediction horizon must be in reasona- 
ble range. However, the argument of high computational burden has already lost much of its relevance owing to the development of faster computing technologies. Hence, more complicated control strategies in this domain can be expected to be realized in near future.
To conduct a comprehensive study of the energy effect of introducing a new control law into the existing automatic control system when the electric drive performs a given technological task, we recommend using the structural diagram in Figure 2.

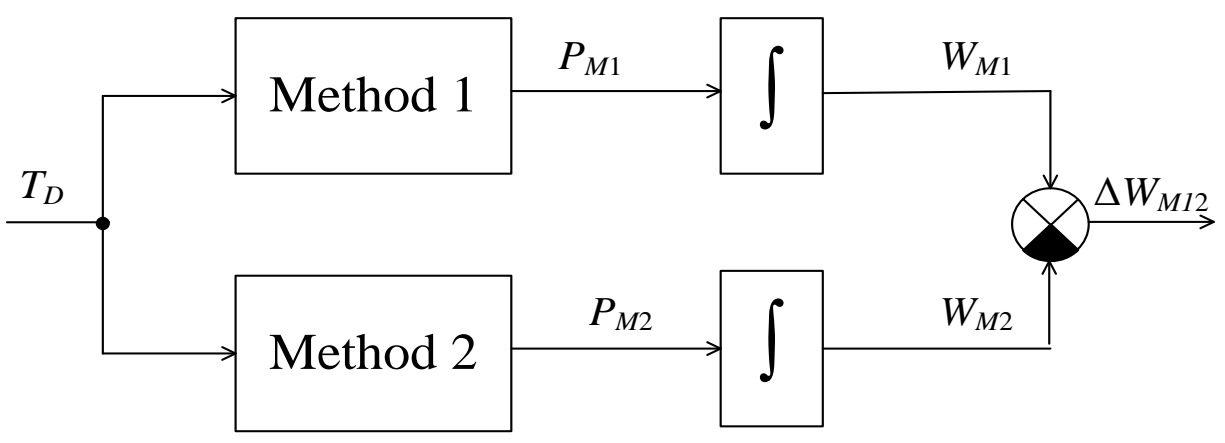

Figure 2 - Process of comparing power losses minimization techniques

For the methods used, power losses and energy losses, determined from their integration $W_{M 1}$ according to method 1 and $W_{M 2}$ for method 2 respectively during the transient process. Figure 2 shows a comparison for $\Delta W_{M 12}=W_{M 1}-W_{M 2}$. Depending on the chosen optimization technique the motor data is used in optimization and a mathematical model describing an induction motor with a rated power selected for research [15]. A detailed analysis of the obtained $\Delta W_{M 12}$ trajectory in such cases will show the advantages and disadvantages of introducing one or another energy-saving law within the existing automated electric drive control system.

With regards to the area of applications, a stepped trajectory of the load torque is possible not only as a result of mechanical disturbance but also occurs when working out the speed reference with constant acceleration and deceleration. Thus, the proposed solution covers a fairly substantial part of the possible applications of an induction motor.

CONCLUSIONS. An iterative loss-minimizing flux control method based on Hamiltonian approach to optimize the rotor flux linkage reference for the vectorcontrolled induction motor drive has been discussed in this paper. Previous research has shown that the proposed approach to the energy efficiency optimization problem for motor torque steps leads to a reduction of power losses during transients compared to conventional methods. In addition, a simple approach to comprehensive analysis of the energy effect of introducing a new loss-minimizing algorithm into the existing automatic control system has been proposed. The main idea is to implement optimization techniques within single control system with further study of obtained transients. The resulting trajectory obtained from Figure 2 shows the cons and pros of introduction one or another optimization technique both in static and dynamic modes of operation. This solution is simple to implement and can be easily integrated in mathematical models for simulation purposes.

\section{REFERENCES}

1. Mazurenko, L., Dzhura, O. (2018), Mathematical model and control of an unregulated wind turbine and IEIG-based isolated energy system, Electromechanical and energy saving systems, 3(43), 24-30. doi:10.30929/2072-2052.2018.3.43.24-30.

2. Maga, D., Zagirnyak, M., Miljavec, D. (2010), Additional losses in permanent magnet brushless machines, Proceedings of EPE-PEMC 2010 - 14th International Power Electronics and Motion Control Conference. (pp. 412-413). doi: 10.1109/EPEPEMC.2010.5606520.

3. Prus, V. V., Zagirnyak, M. V, Kolotylo, I. A., Miljavec, D. (2009), Estimate and taking into account charge of steel losses in induction motors in process of their aging, Proceedings of International IEEE Conference EUROCON 2009. (pp. 777-782). doi: 10.1109/EURCON.2009.5167722.

4. Aksonov, V., Sheremet, A. (2018), Mathematical model of a frequency converter with sensorless vector control, Electromechanical and energy saving systems, 2(42), 37-43. doi:10.30929/2072-2052.2018.2.42.37-43.

5. Starostin, S., Rotkevich, L. (2018), Dynamic properties and trajectory sensitivity of variants of position electromechanical systems, Electromechanical and energy saving systems, 4(44), 8-13. doi:10.30929/2072-2052.2018.4.44.8-13

6. Diachenko, G. G., Aziukovskyi, O. O., Zarichnyi, V. S. (2017), Selection of an appropriate numerical integration method for solving the optimal control problem of an induction motor, Naukovo-tekhnichnyy zbirnyk Natsionalnoho Hirnuchoho Universytetu, 98, 23-30.

7. Pivnyak, G., Dreshpak , N., Vypanasenko, S., Meshcheryakov, L., Zaika, L. (2019), Simulation of electrical heating of materials in metallic capacity of cylindrical form, Solid State Phenomena, 291, 72-82. doi:10.4028/www.scientific.net/SSP.291.72

8. Zhang, D., Shi, J., Zhao, H., Wu, T. (2017), Loss characteristic analysis of small and medium-sized induction motors fed by PWM inverter based on the experiment measurements, IECON 2017 - 43rd Annual Conference of the IEEE Industrial Electronics Society, 

$\begin{array}{llll}\text { (pp. 2053-2058). Beijing, China. } & \\ \text { doi:10.1109/IECON.2017.8216345 }\end{array}$

9. Choudhary, P. K., Dubey, S. P., Tiwari, B., Dewangan, B. (2016), Efficiency optimization of induction motor drive using artificial neural network, 2016 International Conference on Energy Efficient Technologies for Sustainability (ICEETS), (pp. 821827). Nagercoil, India. doi:10.1109/ICEETS.2016.7583860

10. Beshta, O. S. (2012), Electric drives adjustment for improvement of energy efficiency of technological processes, Naukovyi Visnyk Natsionalnoho Hirnychoho Universytetu, 4, 98-107.

11. Hannan, M. A., Ali, J. A., Mohamed, A., Hussain, A. (2018), Optimization techniques to enhance the performance of induction motor drives: A review, Renewable and Sustainable Energy Reviews, 81, 16111626. doi:10.1016/j.rser.2017.05.240
12. Aziukovskyi, O. O., Bakutin, A. V. (2014), Design of optimal high-order speed controller, Naukovyi Visnyk Natsionalnoho Hirnychoho Universytetu, 1, 7176.

13. Diachenko, G. G., Aziukovskyi, O. O. (2018), Control laws of electric drives as a result of an in-depth kinematic analysis of the delta robot, Scientific Bulletin of National Mining University, 1, 106-112. doi:10.29202/nvngu/2018-1/11

14. Czaja, P. (2016), Anti-shock safety of industrial electric installations with built-in frequency converters, 2016 Progress in Applied Electrical Engineering (PAEE), (pp. 1-5). Koscielisko-Zakopane, Poland. doi:10.1109/PAEE.2016.7605113

15. Diachenko, G. G., Aziukovskyi, O. O. (2017), Investigation of the process parameters influence on the energy efficiency of an induction motor under model predictive control GRAMPC, Mechanics, Materials Science \& Engineering, 12. doi:10.2412/mmse.5.86.7

\section{МИНИМИЗАЦИЯ МОЩНОСТИ ПОТЕРЬ И ПОТРЕБЛЯЕМОЙ ЭНЕРГИИ АСИНХРОННЫМИ ДВИГАТЕЛЯМИ С НЕСТАЦИОНАРНОЙ НАГРУЗКОЙ}

\section{Г. Г. Дяченко, А. А. Азюковский}

Национальный технический университет «Днепровская политехника»

просп. Дмитрия Яворницкого, 19, г. Днепр, 49005, Украина. E-mail: diachenko.g @nmu.one

С. Н. Якимец

Кременчугский национальный университет имени Михаила Остроградского

ул. Первомайская, 20, г. Кременчуг, 39600, Украина. E-mail: ysm_seem@meta.ua

Статья направлена на анализ отечественного и зарубежного опыта относительно вопросов одновременного протекания электромагнитных и электромеханических переходных процессов в электромеханической системе с электрическим двигателем на базе асинхронной машины и исследования их влияния в задачах минимизации мощности потерь в обмотках при применении различных законов управления, что в свою очередь ведет к снижению суммарной потребляемой электроэнергии из сети. В процессе исследования была сформирована обобщенная структурная схема, отражающая процесс преобразования потребляемой энергии из сети в механическую мощность как результат взаимодействия вращающегося электромагнитного поля с активной составляющей тока ротора согласно закону сохранения для электромеханического преобразователя, работающего в режиме двигателя. Мы провели математическое моделирование асинхронной машины в составе системы векторного управления с ориентацией по полю ротора с учетом ступенчатой формы изменения траектории момента нагрузки, которая возможна в результате механического возмущения, а также отработке профиля скорости с постоянным ускорением или торможением. Мы разработали математическую модель электромеханической системы управления электродвигателем в рамках системы векторного управления с учетом уравнения динамики потокосцепления и уравнения крутящего момента двигателя полученные непосредственно из схемы замещения. Уставка тока намагничивания является дополнительной степенью свободы в данной системе. Для обеспечения минимальных затрат энергетических ресурсов при достаточной интенсивности протекания переходных процессов в объекте управления реализована модель позволяет проводить сравнительный анализ различных подходов к решению оптимизационной задачи. Впервые был проведен комплексный анализ переходных процессов, когда асинхронная машина работает в режиме с нестационарным нагрузкой и экономического эффекта от внедрения энергоэффективного закона управления при переходном процессе. Рассмотрен подход к минимизации мощности потерь в динамическом режиме работы электромеханической системы с электрическим двигателем на базе асинхронной машины с короткозамкнутым ротором имеет одинаковое формулировки как для оптимизационной задачи в статическом режиме работы, так и в динамическом уменьшает пиковые значения мгновенной мощности потерь при ступенчатом изменении нагрузки на валу электродвигателя. Предложенный итеративный подход к учету энергии потерь и сравнительного анализа эффекта от внедрения различных методов оптимизации дает хорошие результаты даже с простой математической моделью двигателя.

Ключевые слова: минимизация мощности потерь, динамический режим, асинхронный двигатель, нестационарная нагрузка.

Стаття надійшла 01.10.2019. 